\title{
Characteristics of Hydrodynamic Processes in the Meghna Estuary due to Dynamic Whirl Action
}

\author{
Rubayat Alam ${ }^{1}$, Md. Saiful Islam², Md. Raqubul Hasib ${ }^{3}$, \\ Md. Zahirul Haque Khan ${ }^{4}$ \\ ${ }^{1}$ Senior Specialist, Coast Port and Estuary Management Division, Institute of Water Modelling, Bangladesh \\ ${ }^{2}$ Junior Engineer, Coast Port and Estuary Management Division, Institute of Water Modelling, Bangladesh \\ ${ }^{3}$ Junior Engineer, Coast Port and Estuary Management Division, Institute of Water Modelling, Bangladesh \\ ${ }^{4}$ Director, Coast Port and Estuary Management Division, Institute of Water Modelling, Bangladesh
}

\begin{abstract}
The Meghna Estuary region of Bangladesh is a unique environment where the constant process of land formation and erosion takes place due to the complex interactions between large river discharge, enormous sediment load, strong tidal forces, wind actions, wave, salinity \& cyclonic storm surge and estuarine circulation. These hydrodynamic factors and their interactions shape the morphology of the Meghna Estuary. During dry season upland fresh water flow into the Bay through the estuary is very much lower than that of monsoon season. Tidal action becomes stronger and dominates water flow pattern in the Meghna estuary. The distribution of flow and water level in the different channels of the Meghna estuary are governed by river discharge, the tide and the wind speed. Velocity is higher during ebb tide than that of flood tide due to combined effect of upstream flow and downward tidal current. Velocity in monsoon is much higher compare to dry period because upstream discharge is higher in monsoon. Most of the accretion and erosion mainly occurs during monsoon and post monsoon period. In pre-monsoon and post monsoon, wave height is less compared to monsoon as wind speed is less during these periods. Along the left Bank of this estuary, significant wave is considerable. As a result, tremendous whirl action due to tidal effects and whirl action due to enormous drainage flow during monsoon, wave action, tidal surge of the lower Meghna causes breaching of the major parts of the embankments of polder $59 / 2$ and adjacent area. The main purpose of this research paper is to understand the hydrodynamic features of the Meghna estuary.
\end{abstract}

Keywords: - Bay of Bengal Model (BoBM), Flexible Mesh (FM), Ganges-Brahmaputra-Meghna (GBM), Hydrodynamic, Meghna Estuary Study (MES)

\section{INTRODUCTION}

The combined flow of the Ganges-Brahmaputra-Meghna (GBM) is drained through the Lower Meghna River into the Bay of Bengal via the estuary. Among the big rivers in the world, the combined flow of the Ganges-Brahmaputra-Meghna Rivers ranks third in terms of river flow and first in terms of total sediment discharge [1]. There are distinct differences between Brahmaputra and Ganges river regimes [2]. The Brahmaputra rises on average one month earlier than the Ganges, while flow recession in the Ganges river starts earlier that the Brahmaputra. The peak flow in the Brahmaputra occurs during July while in the Ganges River it is delayed until August. Discharge of river water into the Meghna estuary at different seasons is highly skewed. Some of the measurements done during the Meghna Estuary Study project suggest that in an extreme year, discharge through the estuary can be as much as fifteen times during the monsoon season compared to that during the dry season [3]. It reported that in an average year the discharge through the estuary is about 20,000 $\mathrm{m} 3 / \mathrm{s}$ during the dry season whereas it is $100,000 \mathrm{~m} 3 / \mathrm{s}$ during the monsoon [4]. In recent year IWM has measured discharge in the Lower Meghna under a project named as "Detailed Feasibility Study in Connection with Protection of Ramgati and Kamal Nagar Upazila and Adjacent Areas under Laxmipur District from the continuing Erosion of the Meghna River". The discharge through this river varies from about 10,000m3/s in dry season to $160,000 \mathrm{~m} 3 / \mathrm{s}$ in the wet season. In general, dry season (October -March) is the calm period in the estuary with weak wind from north and low river discharge. In contrast, monsoon season (June-September) is more vigorous with strong south-westerly wind and large river discharge and also higher mean water level [5].

The interactions between the river discharge and tidal volume moving through the channels during the premonsoon and post-monsoon period in Lower Meghna Estuary, the estuary can be divided into 3 sub-units, the Tetulia and the west Shahbazpur channel can be termed as 'fluvial (in the sense that river outflow dominates over the tidal inflow)'; the east Shahbazpur and the west Hatiya channels can be termed as 'fluvio-tidal', and the east Hatiya and the Sandwip channels can be termed as 'tidal'. Monpura Island and Char Faizuddin divides the Shahbazpur channel into east and west. Char Nurul Islam divides the Hatiya channel into east and west [6].The 'fluvial' and the 'fluvio-tidal' sub-units as described above act as a tidal river with very high discharges in the 
monsoon whereas the 'tidal' unit behaves as a tidal estuary without significant fresh water discharge from the Feni River. The tide is semidiurnal in nature with two tidal cycles per lunar day of 24 hours 50 minutes duration - each cycle having a period of 12 hours 25 minutes. The interaction between the tidal river and the tidal estuary is induced by the open sea connection with the Bay of Bengal south of the Sandwip Island and by the two channels between the north of Sandwip island and the Noakhali main land. The flow in these two channels is induced by the tide level and phase difference between tidal river and tidal estuary [1].

The present paper focuses on the tidal characteristics of the Meghna Estuary during dry and monsoon period. This paper will help us to identify whether there is any changes in the tidal range, in the distribution of flow in different parts of the estuary. The boundary of the Meghna Estuary is showing in Fig. 1.

\section{EXISTING MODEL UPDATED, CALIBRATION AND VALIDATION}

\subsection{Updated Existing Model}

The research outputs have been based on the simulation results of existing two-dimensional Bay of Bengal Model (BoBM). The modelling system used for the development of Bay of Bengal Model is the MIKE21 FM, which is based on an unstructured flexible mesh consisting of linear triangular elements. The mesh enables to increase the resolution of grid around Islands, along coastline and other area of interest. Bathymetry of the Bay of Bengal with color gradient has been shown in mPWD in Fig. 2.

The coverage of the numerical model is shown in Fig. 2. The coverage of the model area starts from Chandpur on Lower Meghna River to 160 Latitude in the Bay of Bengal. The model applies PWD datum. The computational grid or mesh size decreases (or the resolution increases) towards coastlines and Islands. Intertidal areas are flooded and dried during a tidal cycle, both in nature and in the model.

Two open boundaries are defined in the model, one in the north in the Lower Meghna River at Chandpur and another one in the south in the Southern Bay of Bengal from Vishakhapatnam in India to Gwa Bay in Myanmar. The maximum depth along the southern open boundary of the model area is more than 2000 m.

\subsection{Calibration of the Existing Hydrodynamic Model}

The updated and upgraded two-dimensional hydrodynamic model of the Bay of Bengal has been calibrated against water level and water flow at different locations comparing the model results with field measurement to make the model performance to a satisfactory level. Calibration of water level at Daulatkhan and Ramgati during dry 2012 has shown in Fig. 3. Discharge calibration plot at Ramgati (Spring tide) and Tazumuddin (Neap tide) in dry period, February 2012 has also shown in Fig. 4.

\subsection{Validation of the Existing Hydrodynamic Model}

The model results have also been examined with other set of data of different year and location compared to the data used in the calibration to validate the model. Validation plot of discharge at East Shahbazpur Channel and West Shahbazpur Channel in December 2007 and October 2008 has shown in Fig. 5.

\section{HYDRODYNAMIC CONDITION}

The hydrological processes involved in the Meghna Estuary are tide, current speed, wave, discharge, salinity and sediment transport. The combination of strong river and tidal flow produces a complex flow in the estuary.

\subsection{Flow}

The Lower Meghna River conveys the melt and rain water from the upper catchment of Ganges and Jamuna basins, combined with the Padma River and the upper Meghna basin to the sea. The river discharges of these three major rivers dominate the river inflow in the Meghna estuary.

\subsection{Tide}

Tidal waves approaching the coastal areas of Bangladesh are affected at least by four factors causing amplification and deformation of the wave: 1) Coriolis acceleration, 2) the width of the transitional continental shelf, 3) the coastal geometry and 4) the frictional effects due to fresh water flow and bottom topography [7]. The tidal wave from the Indian Ocean travels through the deep Bay of Bengal and approaches the coast of Bangladesh approximately from the south. It arrives at Heron Point and at Cox's Bazar at about the same time. The extensive shallow area in front of the large delta causes some refraction and distortion. Also some reflection of the tidal wave occurs contributing to a significant amplification of the tidal wave in Hatiya and Sandwip Channels. North of Sandwip Island and Urir Char occurrence of tidal bores has been observed. The water level variation is dominated by a semi-diurnal tide with a considerable variation from neap to spring tides [8]. 


\subsubsection{Seasonal Variation of Meghna Estuary}

In the western part of the coastal area of Bangladesh the average tidal range is approximately $1.5 \mathrm{~m}$. In the area around Sandwip, the tidal range is significantly higher with an average range of over $5.0 \mathrm{~m}$. According to the classification of tides proposed by Davies (1964) the tidal range in the study area can be classified as follows Fig. 1.

- Tetulia river - Chandpur : Micro-tidal - tidal range 0-2 m

- South Bhola - Hatia North: Meso-tidal - tidal range 2-4 m

- East Hatia-Sandwip: Macro-tidal - tidal range $>4 \mathrm{~m}$.

The locations of water level data, collected under different Institute of Water Modelling (IWM) projects are shown in Fig. 6. The maximum, minimum, mean water level and maximum tidal range during measurement period are presented in Table 1.

The tidal range at eastern part of the estuary is higher than that at western part partly due to the changes in the transitional shelf width and partly due to Coriolis acceleration which provides higher tidal ranges along the eastern coast than along the western coast in the northern hemisphere. In this research it shows that the mean tidal range increases up to Sandwip and Urir Char (amplification) after which it gradually gets damped up the estuary along the west Hatia and Shahbazpur channels towards the Lower Meghna River with friction from river flow and bed topography. Available data shows that the recorded maximum tidal range is $8.5 \mathrm{~m}$ during spring tide on 24-08-2008 to 04-11-2008 (half hourly) at Bumni (Channel between Urir Char and Char Elahi) and 8.25 m during spring tide on 03-09-2008 to 28-10-2008 (half hourly) at Gachua (Sandwip channel) [9]. Water level in the estuary and around the east and west coasts of Sandwip island in the Sandwip and Hatia channels show that some reflection of the tidal wave occurs contributing to the increase of tidal range around the northeast and northwest of Sandwip island. This means that if any human intervention is planned or implemented in this area like Noakhali-Sandwip cross-dam, the tidal range will increase as a result and this should be kept in mind. The deformation of the tidal wave with short flooding period and extended ebbing period is also responsible for residual landward transport of fine sediments along the Sandwip and the east Hatia channel [10].The maximum tidal range during 1987-1990 at different locations in the Meghna Estuary has been shown in Table 2 to assess the variation with present scenario.

\subsection{Net Flow}

The net flow distribution through the different channel in the Meghna Estuary is calculated using hydrodynamic model results. The net flow distribution in 14 days covering neap and spring tide is calculated for both dry and monsoon season. Dry season distribution is based on February 2011 and August 2011, which represents the monsoon season distribution for this research. Flow distributions in dry and monsoon period in the study area are shown in Fig. 7 and Fig. 8 respectively. In dry period the net flow of lower Meghna at Chandpur is distributed as $41 \%$ and 59\% through west (right) and east (left) channel near Char Bhairabi. Tetulia is carrying about $21 \%$ of total flow of Lower Meghna and a large portion of the rest of the net flow (about 79\%) is flowing through the West Shahbazpur Channel. The net flow through the Hatiya Channel at North Hatiya appears to be dominated by tide as the flow is directed northwards. About 33\% of river net flow is directed toward upstream through North Hatiya Channel. This tide is again flows back to the Bay through west and East Shahbazpur Channel.

In monsoon, the flow distribution is similar to that of the dry season as shown in Fig. 7 and Fig. 8 respectively; a large percentage of flow is conveyed through East Shahbazpur Channel. As given in Table 3, the river discharge of the Lower Meghna is distributed as $41 \%$ and 59\% near Char Bhairabi and Tetulia is carrying $7 \%$ of the river net flow. Near Char Gazaria, the net flow distribution is 50\% and $43 \%$ through west and East Shahbazpur Channel. About 39\% of Lower Meghna River net flow is flowing out to sea through Hatiya Channel. Near Monpura the net flow distribution is $42 \%$ and 12\% through West and East Shahbazpur Channel. These distributions are determined based on the model results of August 2011 [8].

Hatiya Channel is influenced by tide which results in northward net flow in the channel during dry season. The north tip of Hatiya is experiencing erosion and the flow in Hatiya Channel has increased at present time with respect to 2000 as shown in the MES-II study. Most of the Lower Meghna River flow is conveyed along the west part of the estuary through the West Shahbazpur Channel. This is why net flow is high in this channel compared to the other channels of the river system. Continuous erosion is taking place at the west bank of Kamal Nagar \& Ramgati upazilla. The net monsoon flow in the channel is found relatively higher in this study than that of MES-II and other previous study. The net flow through the Lower Meghna River at the east of Char Bhairabi has increased significantly than its west branch. In MES-II study approximately same net flow was found in the two branches [5]. At present the flow through the east branch is greater than the western branch. Previous result indicates that net flow distribution in the Lower Meghna River is changing. Earlier about $70 \%$ net flow passed through West Shahbazpur Channel and only 10\% flow passed through East Shahbazpur 
Channel in dry period (based on 2007 and 2009 dry flow distribution) at Gazaria. But according to dry flow distribution with present bathymetry and 2011 flow condition, it is observed net flow through East Shahbazpur Channel at Char Gazaria increases and it is $24 \%$. The net flow through West Shahbazpur Channel decreases and it is $40 \%$. In monsoon net flow through East Shahbazpur Channel increases from 24\% to 43\% from 2007 to 2011 [11].Comparison of the two bathymetries in the sediment budget analysis shows erosion in the east branch and deposition in the west branch, which supports this finding. Comparison flow distribution in east and West Shahbazpur Channel at different locations is given in Table 4 shows that east side of Lower Meghna River is gaining more flow over the year based on the MES and other studies. It clearly indicates left branch is more eroding than previous period.

A prominent anti-clockwise circulation is prevailing around the Sandwip Island, which is mainly forced by tide. In the Sandwip channel, the residual anti-clockwise circulation during monsoon is similar to the circulation during dry season, which implies the area is dominated by tide both in dry and monsoon seasons [9]. A Counter-clockwise residual circulation with a northward net flow in the Sandwip Channel is $10000 \mathrm{~m}^{\wedge} 3 / \mathrm{s}$ during the dry season and $15000 \mathrm{~m}^{\wedge} 3 / \mathrm{s}$ during the wet season [11]. The residual flow is forced by tides together with the bathymetry. During the dry season the flow is approximately equal to the river discharge and during the wet season it is approximately one-third to one-sixth of the river discharge. The residual circulation to some extent traps the river water inside the Meghna Estuary and is one of the reasons for the relatively low salinity in the estuary even during the dry season. It is also believed to be important for the morphological development. The net anti-clockwise circulation traps the sediment in this area. The net flow in between Sandwip and Hatia Island is influenced by the river discharge [12]. The direction of residual flow per tidal cycle in the channel between south Hatia and Nijhum Dwip is towards south-east during spring and neap tides and the same for the channel between eastern Nijhum Dwip and Char Baheruddin (i.e., Damar Char) is towards south (i.e., seaward) [13].The residual flow and mean current speed is shown in Fig. 9 and Fig. 10 for dry and wet season respectively.

\subsection{Current speed}

The location of maximum depth average velocity is shown in Fig. 11. The maximum depth average velocity field with contour in the Lower Meghna River during dry and monsoon period has shown in Fig. 12 and Fig. 13. The maximum depth integrated velocity in dry period (Feb-March, 2011) varies from $2.25-1.5 \mathrm{~m} / \mathrm{s}$ along the Kamal Nagar Upazila and it varies from 2.00-1.00 m/s along Ramgati Upazila. Near bank velocity is higher along Kamal Nagar Upazila compare to that of Ramgati Upazila. Kamal Nagar and Ramgati Upazila is the most vulnerable location in the Lower Meghna estuary. In monsoon, current speed is higher compare to dry season. Along the Kamal Nagar Upazila maximum depth average velocity (August, 2011) near the bank varies from 3.50-2.00 m/s and along Ramgati Upazila it varies from $\mathrm{m} 2.25-1.00 \mathrm{~m} / \mathrm{s}$ [9]. The measured, simulated and 1:100 year flood event maximum depth average velocities for monsoon at different locations are presented in the Table 5. The depth average velocity in Lower Meghna, Tetulia, Shahbazpur channel, Sandwip, Monpura and Hatiya channel were measured during September, 1990 and the channel between south Hatiya and Nijhum Dwip were measured during July and August, 1987.

During the monsoon period, residual current in the northern Bay of Bengal may be occasionally dominated by strong South-West monsoon wind (average $4 \sim 5 \mathrm{~m} / \mathrm{s}$ and maximum $20 \sim 30 \mathrm{~m} / \mathrm{s}$ ) which may create back water effects in the Meghna Estuary and alter the salinity distribution in the estuary. During winter (dry) season the counter clockwise circulation in the estuary exists but the circulation becomes weaker and it is not influenced by the weak north-easterly $(1.5 \sim 3 \mathrm{~m} / \mathrm{s})$ wind. Thus, tidal current and Coriolis force were found to be the primary forcing factors that govern the residual circulation in the Meghna Estuary [14].

In order to know the extreme condition, 1:100 yr flood event for Meghna River (1998) has been also simulated. The depth average velocity in this estuary increased significantly for this flood event [8]. Velocity contour of Lower Meghna River for 1:100 yr flood event is shown in Fig. 14.

\subsection{Suspended Sediment Concentration}

The Lower Meghna estuary is the route by which sediment is transported from the major rivers to the Bay of Bengal. On the way down the rivers the grain size distribution of the sediment becomes altered by continual deposition, re-erosion and transport. Much of the coarser sediment becomes trapped on the flood plains of the rivers, only being released at times of flood. The finer fractions are transported into the estuary. Within the Lower Meghna Estuary suspended sediment concentrations are generally high, the particles are fine, cohesive, and prone to flocculate and they are richly organic. The long term morphological development of the entire Lower Meghna Estuary system is strongly affected by the river borne sediment inflow from the main rivers Ganges, Jamuna and Meghna. 
In the Meghna Estuary, there are combined effects of river outflow, tide, wave, and wind although it is not yet known to what extent these parameters dominate the circulation process and drive sediment dispersal mechanisms. Moreover, the main cause may change from season to season and in a few cases from measurement to measurement. In the Lower Meghna Estuary, usually the measurements are related to a set of hydro morphologic conditions. So, an analysis that is suitable for one season or for a specific set of hydro morphologic conditions may not be suitable in another season or for another set of conditions. Again, the Lower Meghna Estuary is hardly ever in steady state. Despite that, it is helpful and essential to at least conceptualize the dominant tidal flow and sediment transport mechanisms and trends [10].The sediment concentration varies during a fortnightly cycle of the spring and neap tides. The variation of sediment concentration shows a tendency to increase towards the spring tide when the maximum depth averaged sediment concentration is about 2 to 5 times higher than at neap tide.

In order to know the variation of suspended sediment characteristics, sediment transport rate and erosion-sedimentation pattern the suspended sediment concentration was measured at different locations during different seasons covering spring and neap tide under various studies. The average SSC measured in 1985 and 1986 near the north-west coast of Sandwip was about $4225 \mathrm{mg} / \mathrm{l}$ and in 2008 during the monsoon period it was $2412 \mathrm{mg} / \mathrm{l}$ at spring tide and $777 \mathrm{mg} / \mathrm{l}$ at neap tide. In the south-west coast of Hatia measured in 1984 and 1985 it was $1230 \mathrm{mg} / \mathrm{l}$ and in 2007 during the monsoon period it was $1488 \mathrm{mg} / \mathrm{l}$ at spring tide and $413 \mathrm{mg} / \mathrm{l}$ at neap tide. In 2007, during the dry period the average SSC at this location was $450 \mathrm{mg} / \mathrm{l}$. Tidal average SSC measured on October 15, 1990 - four days before spring tide in the west Shahbazpur channel, was $265 \mathrm{mg} / \mathrm{l}$ at surface and $430 \mathrm{mg} / \mathrm{l}$ at $1 \mathrm{~m}$ above bottom and in 2007 , it was $626 \mathrm{mg} / \mathrm{l}$ at spring tide and $387 \mathrm{mg} / \mathrm{l}$ at neap tide. During the dry season the average SSC at this location in spring period was $253 \mathrm{mg} / \mathrm{l}$. The mean sediment concentration at Elisha during the dry period in 2012 was $97 \mathrm{mg} / 1$ [9] and [10].

\section{FIGURES AND TABLES}

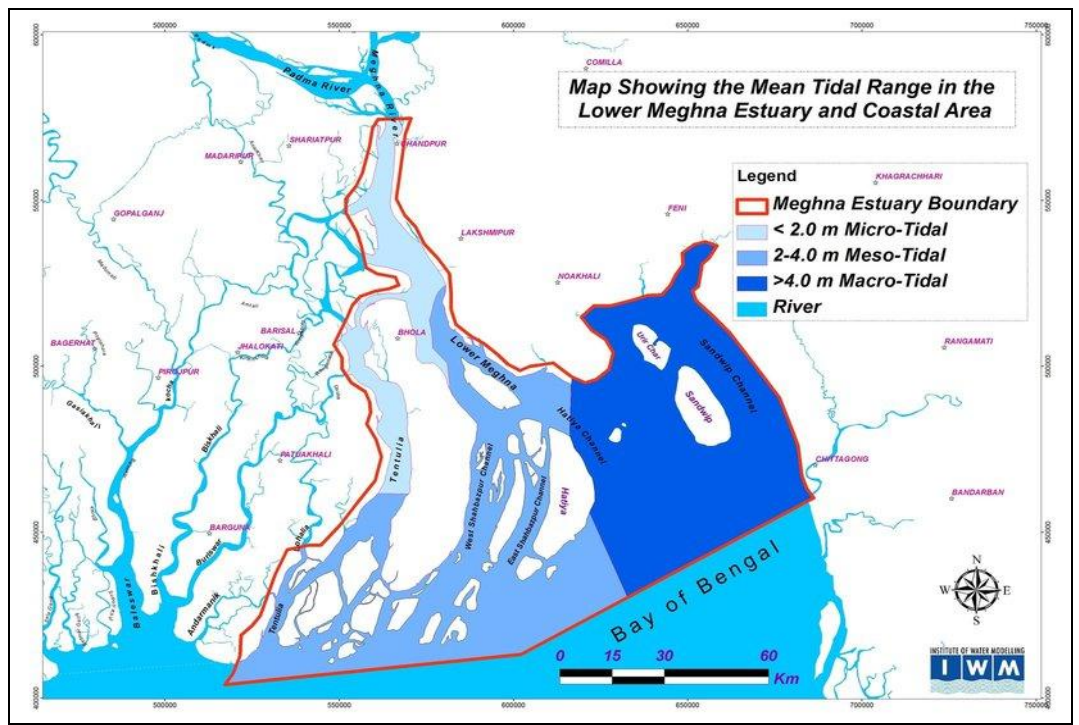

Fig. 1: Area and Mean Tidal range in the Meghna Estuary and Coastal area

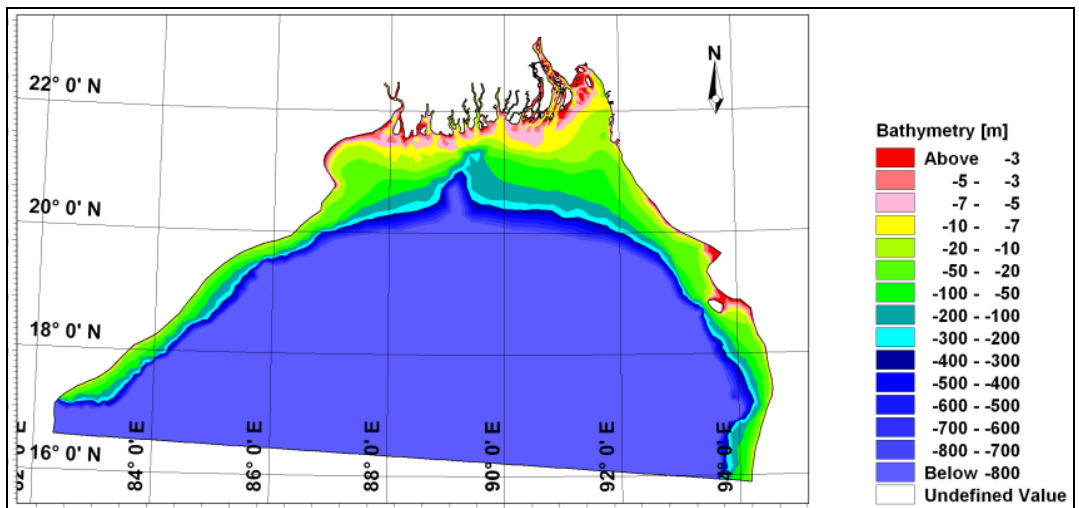

Fig. 2: Bathymetry of the Bay of Bengal where color gradient shows the sea bed level in mPWD 

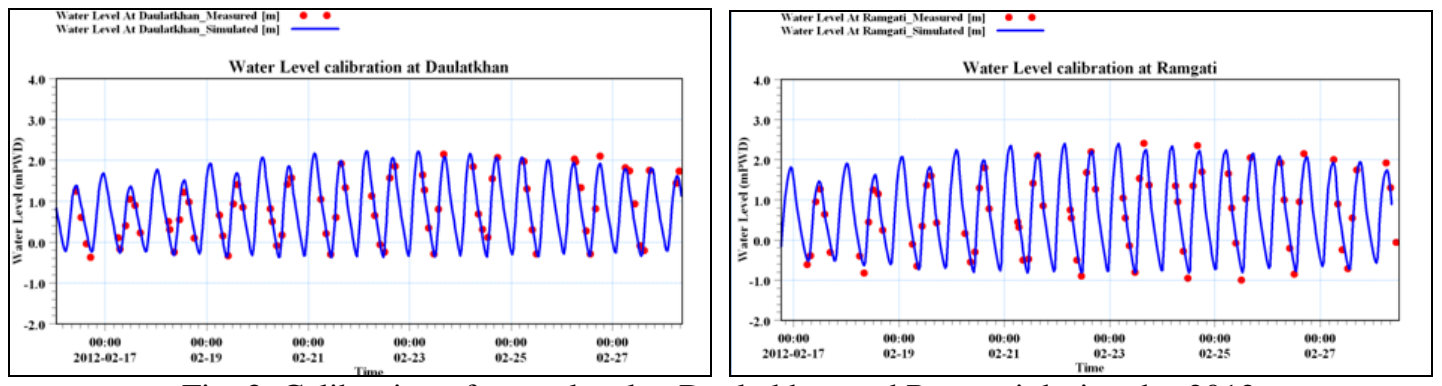

Fig. 3: Calibration of water level at Daulatkhan and Ramgati during dry 2012
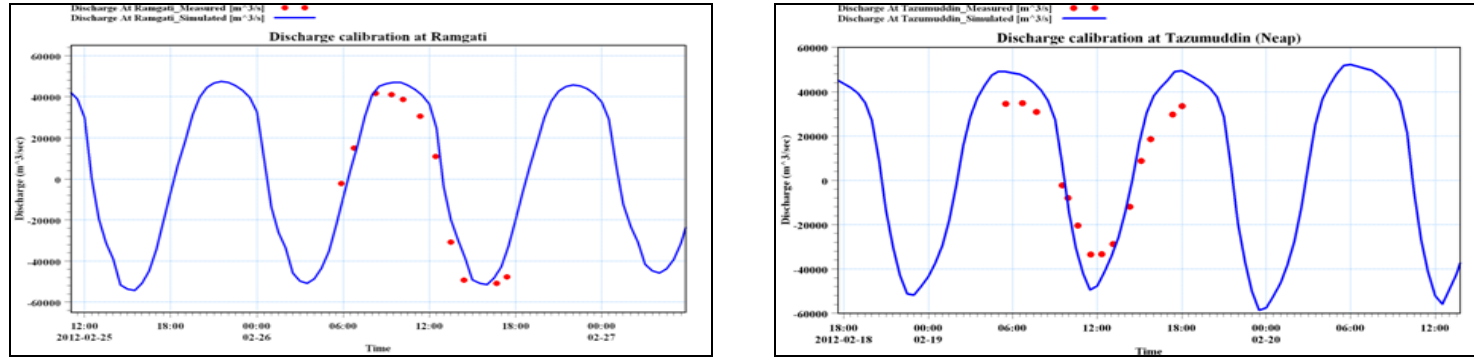

Fig. 4: Discharge calibration plot at Ramgati (Spring tide) and Tazumuddin (Neap tide) in dry period, February 2012
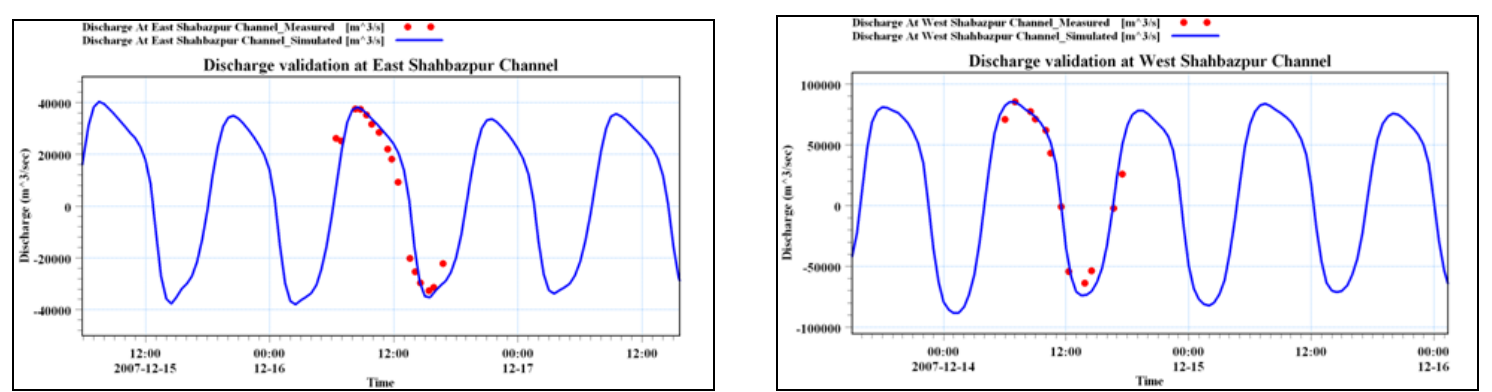

Fig. 5: Validation plot of discharge at East Shahbazpur Channel and West Shahbazpur Channel in December 2007 and October 2008

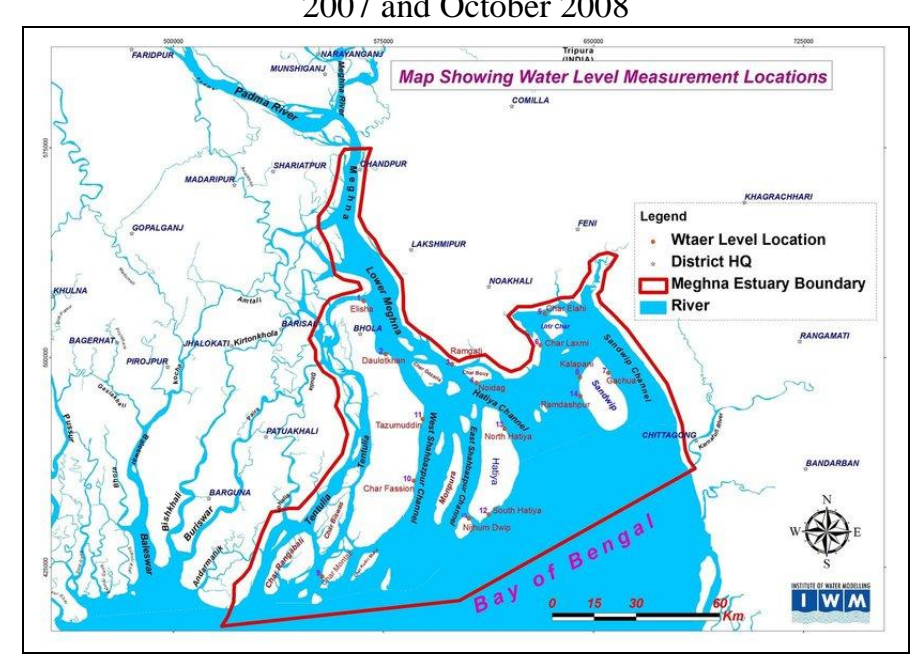

Fig. 6: Water Level measurement locations in the Meghna Estuary 


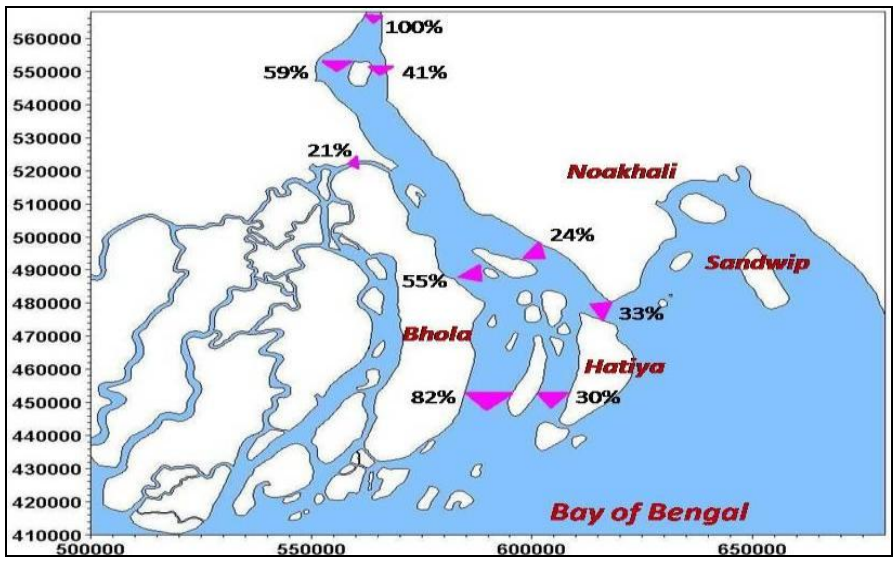

Fig. 7: Net flow distribution in \% of flow at Chandpur during dry season

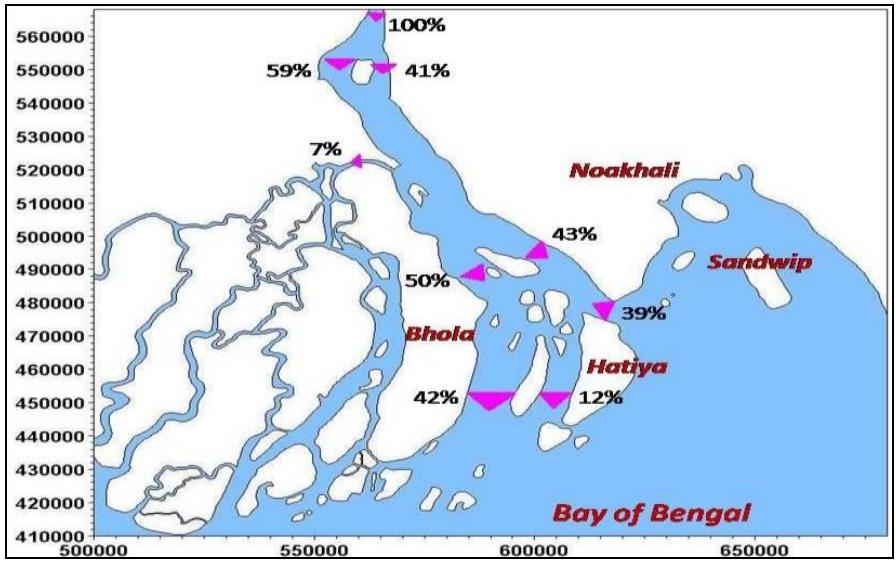

Fig. 8: Net flow distribution in \% of flow at Chandpur during wet season

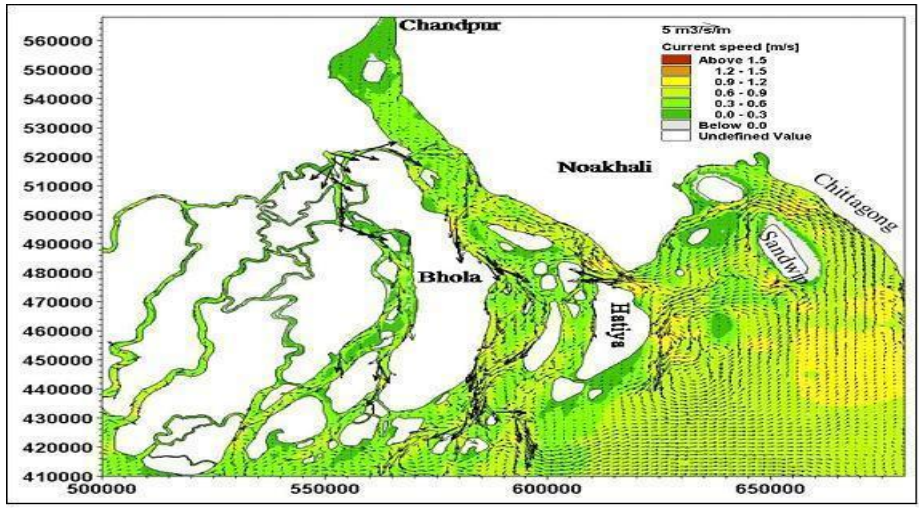

Fig. 9: Residual Flow Pattern in the Meghna Estuary in Dry season (February, 2010)

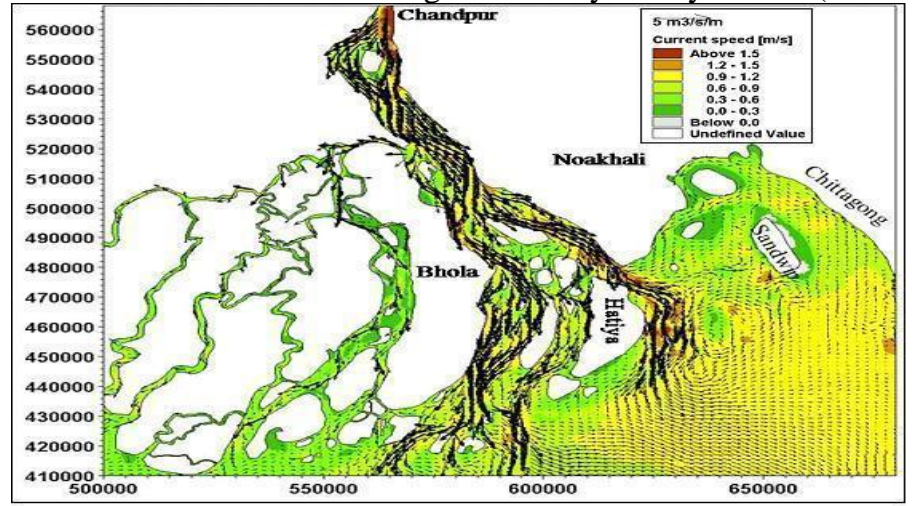

Fig. 10: Residual Flow Pattern in the Meghna Estuary in Wet season (August, 2009) 


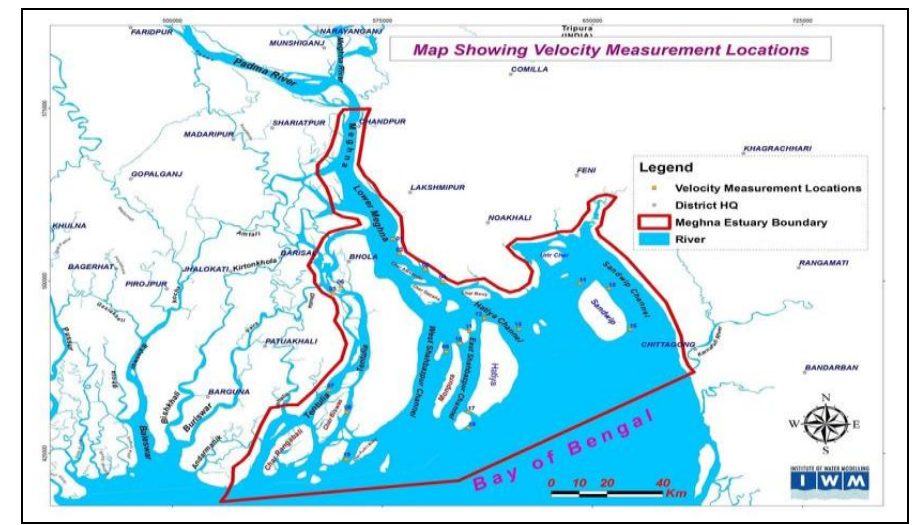

Fig. 11: Location of depth average velocity measurement

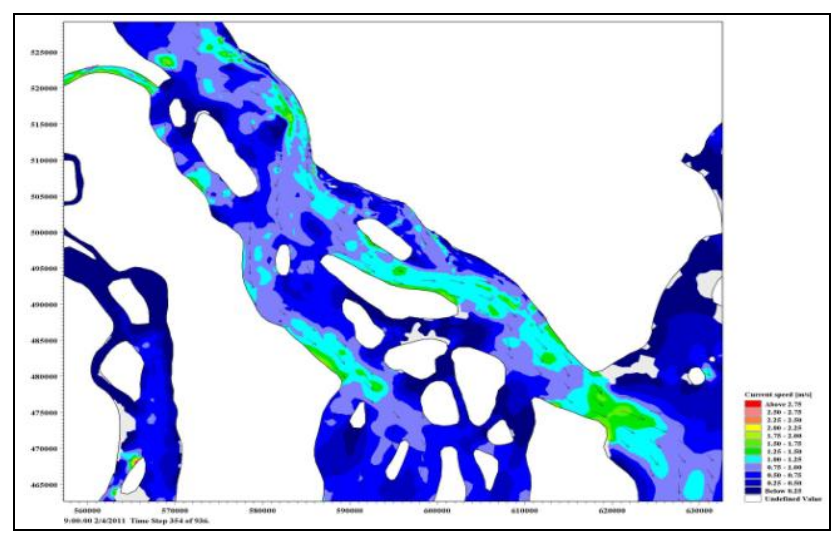

Fig. 12: Depth average velocity in dry period (Feb-March 2011)

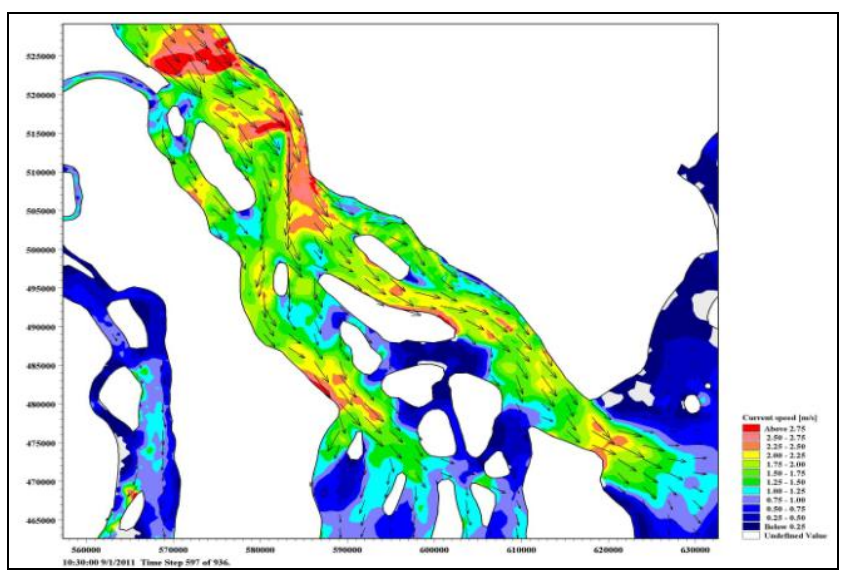

Fig. 13: Depth average velocity in monsoon period (August 2011)

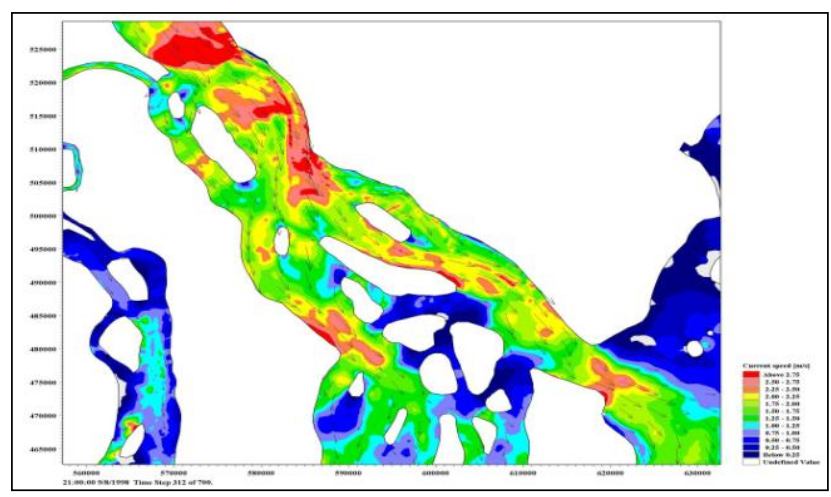

Fig. 14: Depth average velocity for 1998 flood event 
Characteristics of Hydrodynamic Processes in the Meghna Estuary due to Dynamic Whirl Action

Table 1: Maximum tidal range and maximum, minimum and mean water level at different location

\begin{tabular}{|c|c|c|c|c|c|c|c|c|}
\hline $\begin{array}{l}\text { Sl } \\
\text { No }\end{array}$ & Location & Name of the Channel & Duration & Season & $\begin{array}{c}\text { Max } \\
\text { WL(mPIVD) }\end{array}$ & $\underset{\text { Min }}{\text { Min }}$ & $\begin{array}{c}\text { Mean } \\
\text { WL(mPIVD) }\end{array}$ & $\begin{array}{l}\text { Max Tidal } \\
\text { Range (m) }\end{array}$ \\
\hline 1 & Elisha & Tetulia Channel & $\begin{array}{c}22 / 02 / 2012 \text { to } \\
01 / 04 / 2012 \text { (half hourly) }\end{array}$ & Dry & 2.23 & -0.46 & 0.61 & 2.27 \\
\hline 2 & Daulotkhan & $\begin{array}{l}\text { Right bank of West } \\
\text { Shabazpur Channel near } \\
\text { Doulatkhan }\end{array}$ & $\begin{array}{c}16 / 02 / 2012 \text { to } 01 / 04 / 2012 \\
\text { (half hourly) }\end{array}$ & Dry & 2.4 & -1.02 & 0.45 & 3.4 \\
\hline 3 & Ramgati & $\begin{array}{l}\text { Channel between Char zahir- } \\
\text { Uddin and ramgoti }\end{array}$ & $\begin{array}{c}16 / 02 / 2012 \text { to } 31 / 03 / 2012 \\
\text { (half hourly) }\end{array}$ & Dry & 2.9 & -1.79 & 0.45 & 4.07 \\
\hline 4 & Noidag & At Boyer Char & $\begin{array}{c}16 / 02 / 2012 \text { to } \\
01 / 04 / 2012 \text { (half hourly) }\end{array}$ & Dry & 3.44 & -1.81 & 0.59 & 5.01 \\
\hline 5 & Char Elahi & $\begin{array}{l}\text { Bumni (Channel between } \\
\text { Urir Char and Char Elahi) }\end{array}$ & $\begin{array}{c}24-08-2008 \text { to } 04 / 11 / 2008 \\
\text { (half hourly) }\end{array}$ & Monsoon & 6.14 & -2.93 & 1 & 8.5 \\
\hline 6 & Char Laxmi & $\begin{array}{l}\text { Channel between Urir Char } \\
\text { and Noakhali }\end{array}$ & $\begin{array}{c}25-08-2008 \text { to } 04 / 11 / 2008 \\
\text { (half hourly) }\end{array}$ & Monsoon & 5.13 & - & - & - \\
\hline 7 & Gachua & Sandwip channel & $\begin{array}{c}03-09-2008 \text { to } 28 / 10 / 2008 \\
\text { (half hourly) }\end{array}$ & Monsoon & 5.27 & -3.7 & 0.7 & 8.25 \\
\hline 8 & Kalapani & $\begin{array}{l}\text { Channel between Jahazer } \\
\text { Char and Sandwip }\end{array}$ & $\begin{array}{c}01-09-2008 \text { to } 02 / 11 / 2008 \\
\text { (half hourly) }\end{array}$ & Monsoon & 5.96 & -1.94 & 2 & 7.2 \\
\hline \multirow{2}{*}{9} & \multirow{2}{*}{ Char Montaz } & \multirow{2}{*}{$\begin{array}{l}\text { Channel between Char } \\
\text { Montaz and Char } \\
\text { Kukrimukri }\end{array}$} & $\begin{array}{c}08-12-2007 \text { to } 19 / 01 / 2008 \\
\text { (hourly) }\end{array}$ & Dry & 2.09 & -0.07 & 0.88 & 1.91 \\
\hline & & & $\begin{array}{c}17-07-2008 \text { to } \\
13 / 08 / 2008 \text { (hourly) }\end{array}$ & Monsoon & 3.14 & -0.12 & 1.39 & 3.06 \\
\hline \multirow{2}{*}{10} & \multirow{2}{*}{ Char Fassion } & \multirow{2}{*}{$\begin{array}{l}\text { Channel between Char } \\
\text { Fassion and Monpura } \\
\text { (West Shabazpur Channel) }\end{array}$} & \begin{tabular}{|c|}
$\begin{array}{c}08-12-2007 \text { to } 21 / 01 / 2008 \\
\text { (hourly) }\end{array}$ \\
\end{tabular} & Dry & 1.3 & -0.9 & 0.22 & 2.14 \\
\hline & & & $\begin{array}{c}15-07-2008 \text { to } 12 / 08 / 2008 \\
\text { (hourly) }\end{array}$ & Monsoon & 2.8 & -0.43 & 1.12 & 3.2 \\
\hline \multirow{2}{*}{11} & \multirow{2}{*}{ Tazumuddin } & \multirow{2}{*}{$\begin{array}{l}\text { Right bank of West } \\
\text { Shabazpur Channel near } \\
\text { Tazumuddin }\end{array}$} & $\begin{array}{c}07-12-2007 \text { to } 21 / 01 / 2008 \\
\text { (hourly) }\end{array}$ & Dry & 1.68 & -1 & 0.2 & 2.68 \\
\hline & & & $14-07-2008$ to $12 / 08 / 2008$ & Monsoon & 3.49 & -0.41 & 1.24 & 3.89 \\
\hline 12 & Nijhum Dwip & $\begin{array}{l}\text { Channel between Hatiya } \\
\text { and Nijhum Dwip }\end{array}$ & $\begin{array}{c}10-12-2007 \text { to } 23 / 01 / 2008 \\
\text { (hourly) }\end{array}$ & Dry & 2.22 & -0.96 & 0.6 & 3.05 \\
\hline 13 & North Hatiya & $\begin{array}{l}\text { Channel between Hatiya } \\
\text { and South Noakhali }\end{array}$ & $\begin{array}{c}10-12-2007 \text { to } 23 / 01 / 2008 \\
\text { (hourly) }\end{array}$ & Dry & 2.3 & -1.19 & 0.41 & 3.36 \\
\hline 14 & Sandwip & Near West part of Sandwip & $\begin{array}{c}14-12-2007 \text { to } 23 / 01 / 2008 \\
\text { (hourly) }\end{array}$ & Dry & 2.81 & -2.17 & -0.06 & 4.66 \\
\hline 15 & South Hatiya & & $\begin{array}{c}11-07-2008 \text { to } 31 / 07 / 2008 \\
\text { (hourly) }\end{array}$ & Monsoon & 3.21 & -0.41 & 1.33 & 3.39 \\
\hline
\end{tabular}


Characteristics of Hydrodynamic Processes in the Meghna Estuary due to Dynamic Whirl Action

Table 2: Measured maximum tidal range at different location during 1987 to 1990

\begin{tabular}{|c|c|c|c|c|c|c|}
\hline Sl No & Location & Name of the Channel & Duration & Season & $\begin{array}{l}\text { Max Tidal } \\
\text { Range (m) }\end{array}$ & Duration \\
\hline \multirow{2}{*}{1} & \multirow{2}{*}{ Elisha } & \multirow{2}{*}{ Tentulia Channel } & Spring & Dry & & \\
\hline & & & Neap & Monsoon & 2.28 & $02 / 10 / 1987$ \\
\hline \multirow{2}{*}{2} & \multirow{2}{*}{ Daulatkhan } & \multirow{2}{*}{$\begin{array}{l}\text { Right bank of West Shabazpur } \\
\text { Channel near Doulatkhan }\end{array}$} & Spring & Dry & 2.66 & $27 / 02 / 1990$ \\
\hline & & & Neap & Monsoon & 1.45 & $01 / 08 / 1990$ \\
\hline \multirow{2}{*}{3} & \multirow{2}{*}{ Ramgati } & \multirow{2}{*}{$\begin{array}{l}\text { Channel between Char zahir-Uddin } \\
\text { and ramgoti }\end{array}$} & Spring & Dry & 3.00 & $01 / 03 / 1990$ \\
\hline & & & Neap & Monsoon & 1.57 & $02 / 08 / 1990$ \\
\hline \multirow{2}{*}{4} & \multirow{2}{*}{ Noidag } & \multirow{2}{*}{ At Boyer Char } & Spring & & & \\
\hline & & & Neap & Monsoon & 4.06 & $21 / 09 / 1990$ \\
\hline \multirow{2}{*}{5} & \multirow{2}{*}{ Char Elahi } & \multirow{2}{*}{$\begin{array}{l}\text { Bumni (Channel between Urir Char } \\
\text { and Char Elahi) }\end{array}$} & Spring & Dry & 9.00 & $31 / 03 / 1994$ \\
\hline & & & Neap & Dry & 4.21 & $04 / 04 / 1994$ \\
\hline \multirow{2}{*}{6} & \multirow{2}{*}{ Char Laxmi } & \multirow{2}{*}{$\begin{array}{l}\text { Channel between Urir Char and } \\
\text { Noakhali }\end{array}$} & Spring & Dry & 6.30 & $27 / 02 / 1994$ \\
\hline & & & Neap & Dry & 3.90 & $19 / 02 / 1994$ \\
\hline \multirow{2}{*}{7} & \multirow{2}{*}{ Gachua } & \multirow{2}{*}{ Sandwip channel } & Spring & & & \\
\hline & & & Neap & Monsoon & 2.19 & $28 / 09 / 1990$ \\
\hline \multirow{2}{*}{8} & \multirow{2}{*}{ Kalapani } & \multirow{2}{*}{$\begin{array}{l}\text { Channel between Jahazer Char and } \\
\text { Sandwip }\end{array}$} & Spring & & & \\
\hline & & & Neap & Dry & 2.64 & $03 / 03 / 1989$ \\
\hline \multirow{2}{*}{9} & \multirow{2}{*}{ Char Montaz } & \multirow{2}{*}{$\begin{array}{l}\text { Channel between Char Montaz and } \\
\text { Char Kukrimukri }\end{array}$} & Spring & & & \\
\hline & & & Neap & & & \\
\hline \multirow{2}{*}{10} & \multirow{2}{*}{ Char Fassion } & \multirow{2}{*}{$\begin{array}{l}\text { Channel between Char Fassion and } \\
\text { Monpura (West Shabazpur Channel) }\end{array}$} & Spring & Monsoon & 2.70 & $06 / 08 / 1990$ \\
\hline & & & Neap & Monsoon & 1.59 & $13 / 08 / 1990$ \\
\hline 11 & |Tатитuddin & Right bank of West Shabazpur & Spring & Dry & 3.13 & $17 / 03 / 1987$ \\
\hline 11 & 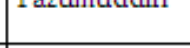 & Channel near Tazumuddin & Neap & Dry & 3.13 & $23 / 03 / 1987$ \\
\hline 12 & Niihum Drxin & Channel between Hatiya and Nijhum & Spring & Dry & 3.32 & $10 / 03 / 1989$ \\
\hline 12 & D & Dwip & Neap & Dry & 1.14 & $31 / 12 / 1987$ \\
\hline 13 & North Hativa & Channel between Hatiya and South & Spring & & & \\
\hline 20 & 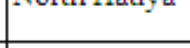 & Noakhali & Neap & Monsoon & 3.03 & $26 / 09 / 1990$ \\
\hline 14 & Sandwip & Near West natt of Sandwin & Spring & Monsoon & 5.89 & $18 / 09 / 1990$ \\
\hline 17 & (Ramdastpur) & 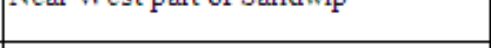 & Neap & Monsoon & 4.62 & $17 / 09 / 1990$ \\
\hline 15 & South Hativa & & Spring & Monsoon & 3.38 & $09 / 09 / 1987$ \\
\hline 19 & 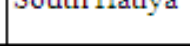 & & Spring & Dry & 3.13 & 09/03/1989 \\
\hline
\end{tabular}

Table 3: Net flow distribution in dry and monsoon period (2011) in the Lower Meghna River

\begin{tabular}{|l|c|c|}
\hline \multicolumn{1}{|c|}{ Location } & Dry Season Net flow & Monsoon Season Net flow \\
\hline Hatiya Channel at North of Hatiya & $33 \%(-\mathrm{ve})$ & $39 \%(+\mathrm{ve})$ \\
\hline East Shahbazpur Channel (at level Monpura) & $30 \%(+\mathrm{ve})$ & $12 \%(+\mathrm{ve})$ \\
\hline West Shahbazpur Channel (at level Monpura) & $82 \%(+\mathrm{ve})$ & $42 \%(+\mathrm{ve})$ \\
\hline Tentulia & $21 \%(+\mathrm{ve})$ & $7 \%(+\mathrm{ve})$ \\
\hline East Shahbazpur Channel (at level Gazaria) & $24 \%(+\mathrm{ve})$ & $43(+\mathrm{ve})$ \\
\hline West Shahbazpur Channel (at level Gazaria) & $55 \%(+\mathrm{ve})$ & $50 \%(+\mathrm{ve})$ \\
\hline Lower Meghna River(West of Char Bhairabi) & $41 \%(+\mathrm{ve})$ & $41 \%(+\mathrm{ve})$ \\
\hline Lower Meghna River(East of Char Bhairabi) & $59 \%(+\mathrm{ve})$ & $59 \%(+\mathrm{ve})$ \\
\hline
\end{tabular}

Note:+ve indicates downward flow -ve indicates upward flow

Flow in the lower Meghna at Chandpur is considered 100\% 
Table 4: Comparison of net flow distribution in east and west branch of Lower Meghna River in different year

\begin{tabular}{|c|c|c|c|c|c|c|}
\hline \multirow{2}{*}{ Location } & \multicolumn{2}{|c|}{$\begin{array}{l}\text { Net flow based on } 2007 \text { flow } \\
\text { condition }\end{array}$} & \multicolumn{2}{|c|}{$\begin{array}{l}\text { Net flow based on } 2009-2010 \\
\text { flow condition }\end{array}$} & \multicolumn{2}{|c|}{$\begin{array}{l}\text { Dry Seas on Net flow based on } \\
\text { February } 2011 \text { flow condition }\end{array}$} \\
\hline & \begin{tabular}{c|c} 
Dry \\
(December 2007)
\end{tabular} & $\begin{array}{c}\text { Monsoon } \\
\text { (August 2007) }\end{array}$ & $\begin{array}{c}\text { Dry } \\
\text { (February 2010) }\end{array}$ & \begin{tabular}{|c|}
$\begin{array}{c}\text { Monsoon } \\
\text { (August 2009) }\end{array}$ \\
\end{tabular} & $\begin{array}{c}\text { Dry } \\
\text { (February }\end{array}$ & $\begin{array}{c}\text { Monsoon } \\
\text { (August 2011) }\end{array}$ \\
\hline $\begin{array}{l}\text { East Shahbazpur Channel } \\
\text { (at level Monpura) }\end{array}$ & $23 \%$ (+ve) & $14 \%$ (+ve) & $25 \%$ (+ve) & $15 \%(+v e)$ & $30 \%(+$ ve $)$ & $12 \%$ (+ve) \\
\hline $\begin{array}{c}\text { West Shahbazpur Channel } \\
\text { (at level Monpura) }\end{array}$ & $67 \%$ (+ve) & $44 \%$ (+ve) & $91 \%(+v e)$ & $51 \%(+v e)$ & $\$ 2 \%(+\mathrm{ve})$ & $42 \%$ (+ve) \\
\hline East Shahbazpur Channel & $8 \%(+v e)$ & $24 \%$ (+ve) & $10 \%(+v e)$ & $40 \%(+v e)$ & $24 \%(+v e)$ & $43 \%(+v e)$ \\
\hline $\begin{array}{c}\text { West Shahbazpur Channel } \\
\text { (at level Gazaria) }\end{array}$ & $68 \%$ (+ve) & $62 \%$ (+ve) & $71 \%(+v e)$ & $51 \%(+v e)$ & $55 \%(+\mathrm{ve})$ & $50 \%$ (+ve) \\
\hline $\begin{array}{c}\text { Lower Meghna River(East } \\
\text { of Char Bhairabi) }\end{array}$ & $39 \%$ (+ve) & $40 \%$ (+ve) & $38 \%(+v e)$ & $41 \%(+v e)$ & $59 \%(+\mathrm{ve})$ & $59 \%(+v e)$ \\
\hline $\begin{array}{c}\text { Lower Meghna River(West } \\
\text { of Char Bhairabi) }\end{array}$ & $61 \%$ (+ve) & $60 \%$ (+ve) & $62 \%(+\mathrm{ve})$ & $59 \%(+\mathrm{ve})$ & $41 \%$ (+ve) & $41 \%$ (+ve) \\
\hline
\end{tabular}

Table 5: Maximum depth average maximum velocity (Model Simulated) at different locations of the study area

\begin{tabular}{|c|c|c|c|c|}
\hline \multirow{2}{*}{ SRL } & \multirow{2}{*}{ Name } & Measured & Simulated( September, 2011) & $\begin{array}{c}1 \text { in } 100 \text { year Flood Event } \\
\text { (August, 1998) }\end{array}$ \\
\hline & & $\begin{array}{c}\text { Depth Average } \\
\text { Maximum Velocity }(\mathrm{m} / \mathrm{s})\end{array}$ & $\begin{array}{l}\text { Depth Average Max } \\
\text { Velocity }(\mathrm{m} / \mathrm{s})\end{array}$ & $\begin{array}{c}\text { Maximum depth average } \\
\text { velocity }(\mathrm{m} / \mathrm{s})\end{array}$ \\
\hline 1 & Kamal Nagar & 1.14 & 2.25 & 3.7 \\
\hline 2 & Char Falcon & 1.5 & 2.6 & 2.8 \\
\hline 3 & Ramgati & 2.3 & 2.25 & 2.6 \\
\hline 4 & Char Algi & 1.4 & 2.17 & 2.2 \\
\hline 5 & Dhulia & 1.07 & 0.97 & 1.25 \\
\hline 6 & Gangapur & 1.42 & 1.25 & 1.6 \\
\hline 7 & West-Char Biswas & 1.57 & 2 & 2.25 \\
\hline 8 & East-Char Biswas & 1.54 & 1.35 & 1.65 \\
\hline 9 & \begin{tabular}{|l} 
North-West Monpura \\
\end{tabular} & 1.74 & 1.67 & 1.85 \\
\hline 10 & North-East Monpura & 1.4 & 1.25 & 1.5 \\
\hline 11 & North-West Hatiya & 2.33 & 2.19 & 2.5 \\
\hline 12 & North Hatiya & 3.13 & 3.05 & 3.25 \\
\hline 13 & North-East Hatiya & 3.6 & 3.25 & 3.86 \\
\hline 14 & North Sandwip & 1.13 & 1.08 & 1.3 \\
\hline 15 & North-East Sandwip & 1.79 & 1.59 & 1.8 \\
\hline \begin{tabular}{l|l|}
16 & \\
\end{tabular} & South -East Sandwip & 1.82 & 1.71 & 1.9 \\
\hline 17 & North-Nijhum Dwip & 2.1 & 1.98 & 2.25 \\
\hline 18 & South-East Nijhum Dwip & 2.2 & 2.05 & 2.5 \\
\hline 19 & Char Montaz & 2.59 & 2.35 & 2.75 \\
\hline
\end{tabular}

IV.

\section{CONCLUSION}

Bay of Bengal model have been updated in order to identify hydraulically active specially erosion prone areas. Updating of the Bay of Bengal Model has been carried out using recent hydro-morphological data and modelling system (MIKE21FM). Hydraulic characteristics, residual flow and mean current speed, the flow distribution in the different channels of the Lower Meghna River has been analysed for dry and monsoon seasons using simulation results. During dry season upland fresh water flow into the Bay through the Lower Meghna River is very much lower than that of monsoon season. Tidal action becomes stronger and dominates water flow pattern in the estuary. The maximum depth average current speeds of about 2 to $3.2 \mathrm{~m} / \mathrm{s}$ are found mainly in the West Shahbazpur Channel, north Hatiya channel and north of Urirchar i.e. in the Bamni channel during monsoon. Lowest velocities of about 0.25-1.0 m/s are found in the upper part of the lower Meghna River during dry period, where the tidal action is less dominant.

Simulation results shows three tidal meeting points in the Sandwip, Jahazerchar and Urirchar area; one in the channel between Urirchar and Char Clark, other meeting point is in the channel between Jahazerchar Char and Noakhali coast near Char Bayejid and another meeting point in the channel between Jahazerchar Char and Sandwip. Model results show that in this area the change of flow direction takes place over a very short distance and rapidly, which is in good agreement with the field observations. A prominent anti-clockwise circulation is prevailing around the Sandwip Island, which is mainly forced by tide. In the Sandwip channel, the residual anticlockwise circulation during monsoon is similar to the circulation during dry season, which implies the area is dominated by tide both in dry and monsoon seasons. The net anti-clockwise circulation traps the sediment in 
this area. The estuary becomes morphologically very dynamic during monsoon. The upland flow is enormous during monsoon and the mean high water is considerably higher than during dry season. The distribution of flow and water level in the different channels of the estuary are governed by river discharge, the tide and the wind speed. Most of the accretion and erosion occurs during monsoon. The morphological characteristics, bankline shifting and erosion and deposition of the different region of the Meghna estuary will be discussed another paper.

\section{ACKNOWLEDGEMENTS}

This research work has been carried out under a collaborative project titled "Detailed Feasibility Study in Connection with Protection of Ramgati and Kamal Nagar Upazila and Adjacent Areas under Laxmipur District from the Continuing erosion of the Meghna River-funded by Bangladesh Water Development Board" and "Morphological Assessment of Meghna Estuary-funded by UNESCO-IHE". The authors are grateful to Institute of Water Modelling (IWM) for the permission to use the essential data and the professionals of the Coast, Port and Estuary Management Division (CPE) who were involved to enrich this paper.

\section{REFERENCES}

[1] J.D. Milliman, Flux and fate of fluvial sediment and water in coastal seas, Mantoura, R.F.C., Martin, J.-M. \& Wollast, R. (Ed.), Ocean Margin Processes in Global Change, John Willey and Sons Ltd., Chichester,1991, 69-89.

[2] J.M. Coleman, Brahmaputra River: Channel processes and sedimentation, Journal of Sedimentary Geology, vol. 3, issue 2-3, 1969, 129-239.

[3] MES, Year 2000 update of trends and processes; addendum to morphological processes, Volume 2 of Draft Masterplan for Meghna Estuary, Technical Note MES-029 , Ministry of Water Resources, Bangladesh Water Development Board, DHV Consultants BV and associates, 2001.

[4] MES, Morphological Processes, Draft Masterplan, Volume 2, Ministry of Water Resources, Bangladesh Water Development Board, DHV Consultants BV and associates,1998.

[5] MES, Tidal volume and sediment transport patterns, Technical Note MES-001, Ministry of Water Resources, Bangladesh Water Development Board, DHV Consultants BV and associates, 1997.6

[6] MoWR, Meghna Estuary Study, Salinity distribution in the estuary, Technical Note MES-004, Ministry of Water Resources, Bangladesh Water Development Board, DHV Consultants BV for DGIS/DANIDA and GOB,1997.

[7] F. Jakobsen, M.H Azam, M.M. Kabir, Residual flow in the Meghna Estuary on the coastline of Bangladesh, Journal of Estuarine, Coastal and Shelf Science, 2002, 55: 587-597.

[8] IWM, Detailed Feasibility Study in Connection with Protection of Ramgati and Kamal Nagar Upazilla and Adjacent Areas under Laxmipur District from the Continuing erosion of the Meghna River, Final Report, Bangladesh Water Development Board,2013.9

[9] IWM, Morphological Assessment of Meghna Estuary, Bangla-Dutch Research Initiative on Flood Risk Management and Morphological Assessment, Mid Term Progress Report, UNESCO-IHE, 2012.

[10] D.K. Barua, Suspended Sediment Movement in the Estuary of the Ganges-Brahmaputra-Meghna River System, Marine Geology, 1990, 243-253

[11] M. A Hussain, M. A Hossain ,A. Haque, Numerical Investigation of Residual Currents in the Meghna Estuary of Bangladesh, Proc.3rd International Conf. on Estuary and Coast (ICEC), Sendai, Japan, 2009,142-149.

[12] M.H. Azam, F Jakobsen, M.U. Kabir, J. M. A. Hye, Sensitivity of the tidal signal around Meghna Estuary to the changes in river discharge: a model study, Proc. 12th Congress of the Asia and Pacific Division of the International Association for Hydraulic Engineering and Research, Bangkok, Thailand, 2000, 375384.

[13] S. Ahmed, Residual Tidal and Sediment volume, their circulation patterns and Land cover changes in the Meghna Estuary, Journal of Civil Engineering, Institute of Engineers Bangladesh, Vol. CE 26, No. 1, 1998.

[14] M. A Hussain, M. A Hossain ,A. Haque, Numerical Investigation of Residual Currents in the Meghna Estuary of Bangladesh, Proc.3rd International Conf. on Estuary and Coast (ICEC), Sendai, Japan, 2009,142-14. 